\title{
AOR
}

Selected Papers of \#AolR2019:

The $20^{\text {th }}$ Annual Conference of the Association of Internet Researchers Brisbane, Australia / 2-5 October 2019

\section{INTERNET SAFETY EDUCATION: HOW WE EDUCATE OUR GIRLS TO BEWARE OF OTHERS, AND OUR BOYS TO BEWARE OF THEMSELVES}

Nili Steinfeld

Ariel University

\section{Introduction}

Alongside its many advantages, the Internet presents a variety of challenges and risks to adolescents, which occupy parents and teachers, as well as adolescents themselves. From a perspective focusing on information flow processes, or "information flux" (Bossewitch \& Sinnreich, 2012), these can be roughly divided into risks resulting from exposure to information, i.e. exposure of adolescents to inappropriate content: Harmful, sexual or violent (Boyd \& Hargittai, 2013; Ktoridou, Eteokleous, \& Zahariadou, 2012; Livingstone \& Smith, 2014) and risks resulting from exposure of information, i.e. disclosure of personal information online, privacy harms inflicted by the user or others (Marwick \& Boyd, 2014), misuse of the information which can result in identity theft, physical and sexual assault (Gadekar \& Pant, 2015; Notten \& Nikken, 2016; Shin \& Lwin, 2017).

Research on gender differences in internet usage points to several trends. Alongside a general perception that boys spend more time on games and girls on social networks (Borca et al., 2015) other studies found little gender variance in type of activities (Gross, 2004; Livingstone et al., 2014). Girls share more self-images, however boys share identifiable information and use less strict privacy settings on SNSs (Gadekar, \& Pant, 2015). Girls are more careful online (ibid.), but research reports no significant gender differences with respect to involvement with strangers online or exposure to sexual content (Livingstone et al., 2014).

\section{Research Questions}

Suggested Citation (APA): Steinfeld, Nili. (2019, October 2-5). Internet Safety Education: How we educate our girls to beware of others, and our boys to beware of themselves. Paper presented at AoIR 2019: The $20^{\text {th }}$ Annual Conference of the Association of Internet Researchers. Brisbane, Australia: AolR. Retrieved from http://spir.aoir.org. 
The study's main assumption is that perceptions of gender differences in adolescents' online uses and risks lead to differences in emphasis of educational messages delivered by parents and teachers to adolescents.

Therefore, the study asks:

RQ1. What differences exist between boys and girls with respect to online usage, and are they aligned with adolescents and parents' general perceptions?

$\mathrm{H} 1.1$. Boys spend more time playing online games, girls spend more time on SNSs, in practice as well as perceived.

H1.2. A general perception contends that girls share more personal information online and they are in a greater risk of pedophilia, and boys are more risk seekers and in a greater risk to consume inappropriate content online.

RQ2: What are the gender differences in educational messages by parent and teachers to adolescents regarding safe surfing?

$\mathrm{H} 2$. Messages directed at boys emphasize risks resulting from exposure to (inappropriate) information, whereas messages directed at girls emphasize risks resulting from exposure of (personal) information.

\section{Methodology}

A mixed-method study included survey conducted among 513 adolescents and 50 semi-structured interviews with adolescents, parents and teachers. The study examined surfing habits, exposure to violent, harmful or sexual content, adolescents and parents' online concerns, parental mediation, monitoring and educational activities and messages. Interviewees were requested to think of gender differences in adolescents' online habits, risks and in parents' education for safe surfing.

\section{Findings}

In accordance with H1.1. it was found that girls spend more time in SNSs. Boys spend more time playing online games. These differences are in-line with perceptions of gender differences in usage as repeatedly expressed in the interviews ("Girls surf. Boys play"). Gaming activities are perceived as less social, although they usually involve interactions with other users online.

Regarding $\mathrm{H} 1.2$, girls were more often mentioned in interviews regarding sharing photos and videos of themselves. Boys were described as "nosy", naughty, occupied by "teenage boys' stuff" and actively searching for sexual content ("You know which websites they enter..."). Survey findings partially support these perceptions. Girls post more content to social media. Boys reported being exposed to sexual content more than girls, but no differences were found regarding exposure to violence or bullying.

With respect to risks, the survey indicates girls are more concerned than boys about almost every aspect of online risks, including exposure of information about them to others and being exposed to inappropriate content. Interviewees repeatedly stated there are hardly any gender differences with respect to risks, however girls were perceived as more vulnerable, mentioned mostly with relation to risks of strangers and online predators, and boys with relation to risk of consuming violent and sexual content 
representing distorted realities ("Naturally with the girls I am more concerned that some guy will contact them [...] with the boys [...] I don't think there are boys who haven't visited porn sites").

With respect to $\mathrm{H} 2$, although a general statement of no gender differences in educational messages, in practice several differences repeated in the interviews. Messages to boys emphasize risks of exposing oneself to inappropriate, violent or sexual content. Messages to girls emphasize implications of uploading personal, revealing or provocative content. Survey findings indicate significant differences in parental monitoring of adolescents' online activities, such that boys are more monitored or limited in searching activities, general surfing and search for movies. Girls are more monitored and limited in posting information about themselves.

\section{Conclusions}

The findings indicate several gender differences in usage, perceived risks and education of adolescents. There is a common perception that girls share more personal information online and perceived as being at more risk of online predators. Accordingly, more emphasis is given to implications of personal information disclosure. Boys are considered naughty and nosy, searching for "forbidden", mainly sexual, content, and emphasis is given on limiting and monitoring their searches and video consumption. Apparently, although parents, teachers and adolescents proclaim to be aware of the similar risks to boys and girls online, there is a message interwoven in internet safety education discourse: Girls are to be aware of others looking to harm them, and boys are to be aware of themselves, their curiosity and evil inclination.

\section{References}

Borca, G., Bina, M., Keller, P. S., Gilbert, L. R., \& Begotti, T. (2015). Internet use and developmental tasks: Adolescents' point of view. Computers in Human Behavior, 52, 49-58.

Bossewitch, J., \& Sinnreich, A. (2013). The end of forgetting: Strategic agency beyond the panopticon. New Media \& Society, 15(2), 224-242.

Boyd, D., \& Hargittai, E. (2013). Connected and concerned: variation in parents' online safety concerns. Policy \& Internet, 5(3), 245- 269.

Gadekar, R., \& Pant. S. (2015). Exploring facebook users' privacy knowledge, enactment and attitude: a study on Indian youth. International Journal of Communication Research, 5(4), 273.

Gross, E. F. (2004). Adolescent Internet use: What we expect, what teens report. Journal of Developmental Psychology, 25(6), 633-649.

Ktoridou, D., Eteokleous, N., \& Zahariadou, A. (2012). Exploring parents' and children's awareness on internet threats in relation to internet safety. Campus-wide information systems, 29(3), 133-143. 
Livingstone, S., Mascheroni, G., Ólafsson, K., \& Haddon, L. (2014). Children's online risks and opportunities: Comparative findings from EU Kids Online and Net Children Go Mobile.

Livingstone, S., \& Smith, P. K. (2014). Annual research review: Harms experienced by child users of online and mobile technologies: The nature, prevalence and management of sexual and aggressive risks in the digital age. Journal of child psychology and psychiatry, 55(6), 635-654.

Marwick, A. E., \& Boyd, D. (2014). Networked privacy: How teenagers negotiate context in social media. New Media \& Society, 16(7), 1051-1067.

Notten, N., \& Nikken, P. (2016). Boys and girls taking risks online: A gendered perspective on social context and adolescents' risky online behavior. new media \& society, 18(4), 966-988.

Shin, W., \& Lwin, M. O. (2016). How does "talking about the Internet with others" affect teenagers' experience of online risks? The role of active mediation by parents, peers, and school teachers. New Media \& Society, 19(7), 1109-1126. 